\title{
BANKING SECTOR: STATE BANKS GENERATE ALL PROFIT
}

M.Khromov

In Q1 2016, the banking sector earnings went up significantly compared to last year. This fact has noticeably maintained the banking sector capitalization by offsetting a reduction of other sources of banks' own funds. However, the profits generated by regular bank transactions remain noticeably lower than it was during pre-crisis period. Earnings continue to concentrate in major Russian bank - Sberbank and other major banks.

In $\mathrm{H} 1$ 2016, the Russian banking sector balance profits hit Rb 360 bn. It is 7-fold more than a year earlier (in H1 2015 the banking system generated only $\mathrm{Rb} 51$ bn of profits) and nearly twice as much as throughout 2015 when the banking sector profits totaled $\mathrm{Rb} 192 \mathrm{bn}$.

In H1 2016, return on assets (ROA) amounted to $0.9 \%$ on a year-on-year basis, which corresponds the 2014 level as a whole. However, then up to December assets profitability remained at a far higher level - around $1.5 \%$ year-on-year. Thus, despite a significant growth of profits generated by the banking sector, its volume remains quite moderate in comparison with pre-crisis levels. In 20112012, profitability of bank assets exceeded $2.0 \%$ year-on-year.

The major part of half-year profits was shown in June 2016: Rb 126 bn, in other words more than one third of total profits generated during six months. June happened to be the most profitable month for the banking sector taken in nominal terms. The previous regarding volume result was registered in June 2014 when banks generated Rb 114 bn. At the same time, even such record volume of monthly profits happens to be not too significant from the point of view of assets profitability. In June, it constituted barely $1.9 \%$ year-on-year.

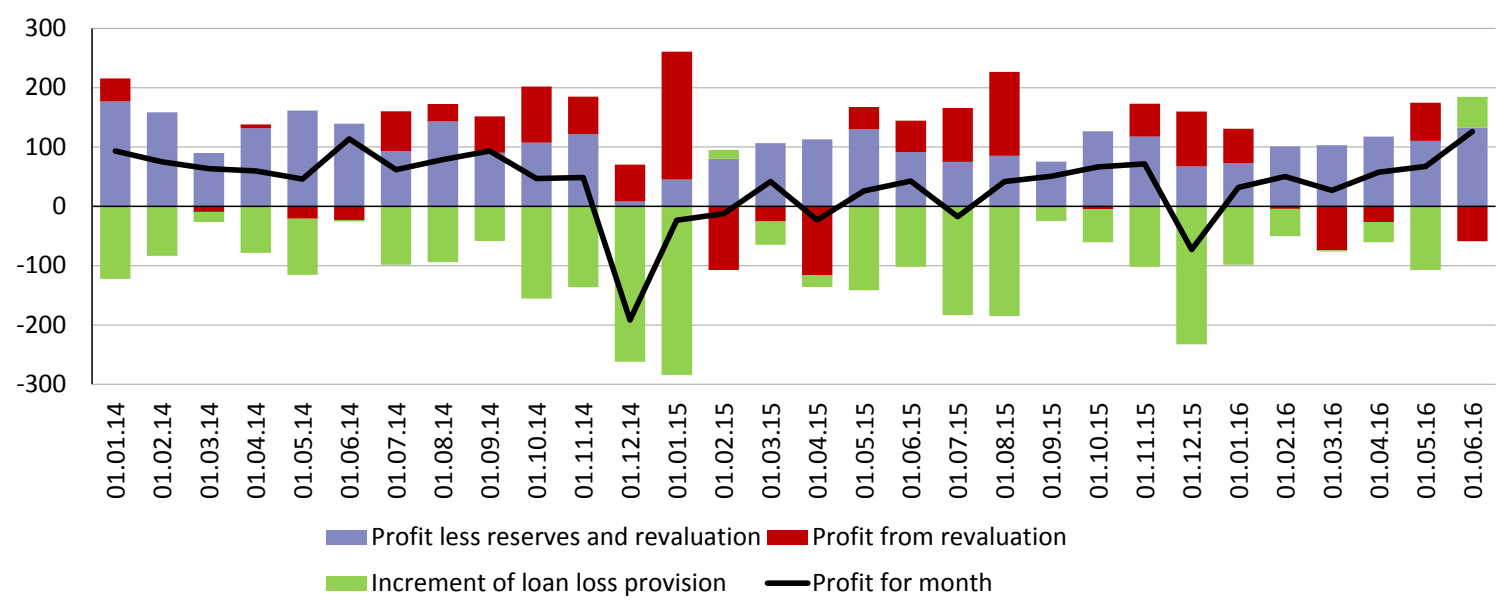

Sources: Bank of Russia, IEP calculations.

Fig. 1. The main components of the banking sector profits, $R b b n$

1 This paper was originally published in Online Monitoring of Russia's Economic Outlook No.13(31). 
The structure of the bank's profits demonstrates a reduction of its "crisis" components - formation of reserves against potential losses and earnings obtained from the exchange rate revaluation. For example, throughout H1 2016, growth of reserves against loan and other assets losses constituted Rb $237 \mathrm{bn}$. This is even less than for the corresponding period of 2013 ( $\mathrm{Rb} 260$ bn), not to speak of 2014 (Rb 399 bn) and 2015 (Rb 517 bn). Hereby, reduction of provisions for potential losses, in other words a slowdown of risk growth in bank assets, became the major factor of the banking sector profitability growth registered in 2016.

At the same time, the net earnings generated from the revaluation of accounts denominated in foreign currency went down. In H1 2016, it was negative ( $\mathrm{Rb}-41 \mathrm{bn})$, meanwhile a year ago throughout the same period banks earned due to a decline of the ruble exchange rate $\mathrm{Rb} 52 \mathrm{bn}$. This was owing to a growth of the national currency cost. In H1 2016, ruble appreciated to the US dollar by $12,0 \%$ and to euro - by $10.5 \%$. In H1 2015, ruble/ USD rate practically remained unchanged, appreciation came to $0.7 \%$, and appreciation to euro amounted to $8.8 \%$.

Regarding banks earnings generated from the regular bank transactions, i.e. minus growth of reserves against potential losses and the net income obtained from revaluation of currency accounts, its growth happened to be not so impressive. During $\mathrm{H} 1$, the banks earned $\mathrm{Rb} 638 \mathrm{bn}$ from these transactions, which is only by $12.5 \%$ more than in $\mathrm{H} 12015$ (Rb 566bn). Return on assets along this component of earnings has not practically changed during the year, totaling $1.6 \%$ year-on-year in comparison with $1.5 \%$ in $\mathrm{H} 12015$. For comparison, up to 2014, in $\mathrm{H} 1$ banks managed to generate profit from regular transactions equivalent to $2.7-2.9 \%$ of the average assets volume in annual terms. This means that at present profitability from main bank transactions is nearly half of its regular level characteristic for periods of stable development of the banking sector.

Nevertheless, banks' profits growth in 2016 has allowed to maintain the level of the banking sector' own funds. For the first five months ${ }^{1}$ of 2016, the amount of aggregate own funds of the banking sector has contracted by $\mathrm{Rb} 44 \mathrm{bn}$. At the same time, reduction of the subordinated credits volume accounted in the banks' own funds has mainly contributed to the contraction of capital. In the course of five months, it fell by Rb $232 \mathrm{bn}$. Positive financial result obtained by the banks over this period allowed to level the indicator of own funds reduction. As a result, capital adequacy ratio during the turn of the year has dropped by barely 0.3 p.p. from $12.7 \%$ as of 1 January 2016 to 12.4\% as of 1 June 2016.

Major portion of banks earnings as before accrues to one major bank Sberbank. In H1 2016, earnings of Sberbank hit Rb 299bn - more than 88\% of the earnings of entire banking sector. In other words, Sberbank, which accounts for less than $30 \%$ of the total assets of the banking sector, has generated five time more profits than all other banks. However, this is the move to normalizing the distribution of profits in the banking sector because by the end-2015 earnings of Sberbank ( $\mathrm{Rb} 282 \mathrm{bn}$ ) exceeded earnings of the entire banking sector (Rb 192bn) - other banks in the whole showed a loss.

1 At the time of preparation of this material, the Bank of Russia has not released data on own funds and prudential supervision ratios as of 1 July 2016. 
If we add to Sberbank those banks, which are affiliated to the RF Government and to the major state company Gazprom, ${ }^{1}$ then it will turn out that nearly all bank income is accounted for major state banks. On aggregate, they generated $\mathrm{Rb} 356 \mathrm{bn}$ of earnings out of $\mathrm{Rb} 360 \mathrm{bn}$ generated to the entire banking sector. This means that other private banks are teetering on the brink of zero profitability. Private segment of the banking sector remains extremely unattractive from the investment point of view for the banks' owners. Support of banks by private capital is primarily hampered by considerations of existing business survival in the absence of significant investments into faster growth. Most likely, this fact will lead to further consolidation of state banks on the banking facilities market and continued growth of assets concentration in the banking sector.

1 Banks of VTB group (VTB, VTB24 and Bank of Moscow), Rosselkhozbank and GPB. 